\title{
Comparison of retroviral p15E-related factors and interferon $\alpha$ in head and neck cancer
}

\author{
Peter J. Simons ${ }^{1}$, Robert A. J. Oostendorp², Maarten P. R. Tas ${ }^{3}$, Hemmo A. Drexhage ${ }^{1}$ \\ 1 Department of Immunology, Erasmus University, Rotterdam, The Netherlands \\ 2 GSF-Forschungszentrum für Umwelt und Gesundheit, Institut für Experimentelle Hämatologie, München, Germany \\ ${ }^{3}$ Department of Microbiology, University of Leicester, Leicester, Great Britain
}

Received: 9 September 1993/Accepted: 7 October 1993

\begin{abstract}
Head and neck squamous cell carcinomas (HNscc) produce low-molecular-mass factors (low- $M_{\mathrm{r}}$ factors, $M_{\mathrm{r}} \leq 25,000$ ), which are antigenically related to the immunosuppressive retroviral transmembrane envelope protein $\mathrm{p} 15 \mathrm{E}$. These P15E-related tumour factors are thought to be responsible for some immunological impairments found in these patients (particularly the defective monocyte chemotaxis). A sequential and functional homology has been reported to exist between a bioactive fragment of interferon $\alpha$ (IFN $\alpha$ ) and the putative immunosuppressive region of retroviral p15E (CKS-17). In this study we investigated (a) a possible functional and structural relationship between p15E and IFN $\alpha$, and (b) the presence of and the relationship between p15E-related low$M_{\mathrm{r}}$ factors and IFN $\alpha$ in HNscc patients. We report the following results. (a) Recombinant human (rhu) IFN $\alpha$ was able to inhibit monocyte chemotaxis. (b) The anti-p15E antibodies crossreacted with rhuIFN $\alpha$ in a dot-blot technique; however, the anti-IFN $\alpha$ antibodies did not crossreact with disrupted murine leukaemia virus (p15E source). (c) Low- $M_{\mathrm{r}}$ factors $(n=8-11)$ prepared from the sera of HNscc patients, which inhibit the monocyte chemotactic responsiveness, could be adsorbed by the anti-p $15 \mathrm{E}$ antibodies as well as by the anti-IFN $\alpha$ antibodies. However, the abilities of the factors to adsorb to the two categories of antibodies (namely, anti-p15E and anti-IFN $\alpha$ ) did not correlate. (d) Immunohistochemically we found IFNo-related epitopes, in almost all HNscc specimens studied (17/18), in locations distinctive from those of p15E-related factors. The anti-IFN $\alpha$ antibodies used in this study mainly reacted with basal epithelial cells close to the basal membrane, the prickle and granular cells of the squamous cell carcinomas. The anti-p15E antibodies mainly reacted with corneal layers, the granular and prickle cells, and did not react with
\end{abstract}

Correspondence to: P. J. Simons, Department of Immunology, Erasmus University Rotterdam, P. O. Box 1738, 3000 DR Rotterdam, The Netherlands basal epithelial cells. Our findings suggest that the immunosuppressive factors produced by HNscc cells are heterogeneous and p15E- and/or IFN $\alpha$-related.

Key words: p15E - IFN $\alpha$ - Monocyte - Immunosuppression - Head and neck cancer

\section{Introduction}

Head and neck squamous cell carcinoma (HNscc) patients show several defects in cell-mediated immunity [1], most notably in chemotactic responsiveness of blood monocytes [2]. Removal of the HNsce restores this defective chemotactic responsiveness [3], indicating that the tumor produces immunosuppressive factors. Indeed, low-molecularmass factors (low- $M_{\mathrm{r}}$ factors, $M_{\mathrm{r}} \leq 25,000$ ), which inhibit monocyte and macrophage responses to chemotaxins, have been detected in tumor specimens $[4,5]$ and sera $[6-8]$ of HNscc patients. Interestingly, the effect of these factors has been shown to be abrogated with monoclonal antibodies $(\mathrm{mAb})$ directed against a retroviral immunosuppressive protein, p15E. This was taken as evidence that these low- $M_{\mathrm{r}}$ factors were structurally related to $\mathrm{p} 15 \mathrm{E}$, and possibly involved in hampering the defense immune response towards cancer cells.

$\mathrm{P} 15 \mathrm{E}$ is the transmembrane envelope protein of several animal leukaemogenic retroviruses, such as murine leukaemia virus (MuLV) and feline leukaemia virus (FeLV), and is well known for its immunosuppressive actions (reviewed in $[9,10]$ ). A synthetic 17-amino-acid peptide (CKS-17), homologous to a highly conserved region in several retroviral transmembrane envelope proteins [11], has similar immunosuppressive actions, amongst which are inhibition of monocyte chemotactic responsiveness [12], interleukin-1(IL-1)-mediated monocyte tumour killing [13], the respiratory burst of human monocytes [14], the mitogen- and alloantigen-stimulated proliferation of human 
lymphocytes $[15,16]$, immunoglobulin synthesis by B lymphocytes [17], interferon $\gamma$ (IFN $\gamma$ ) production [18], human natural killer (NK) cell activity [19], and in vivo delayed-type hypersensitivity (DTH) to sheep red blood cells in mice [20].

Recently, Ruegg et al. [21] identified a CKS-17-like conserved region in human interferon $\alpha$ (IFN $\alpha$ ), a small fragment which, when presented as a synthetic peptide, inhibited proliferation of both the Daudi lymphoblastoid cell line and anti-CD3-stimulated human T lymphocytes. This fragment exhibited a high degree of amino acid sequential identity $(70 \%)$ to CKS-17. Recombinant human (rhu) IFNo (subtype 2) has a similar antiproliferative action. Wegemer et al. [22] have found a peptide ( $\mathrm{P}^{+}$:ISP) comprised of CKS-17 linked to another p15E-derived sequence (rich in polar positive residues) from FeLV, which like IFN $\alpha$ showed antiviral activity on feline- and murinevirus-infected cell lines. These authors postulated that some of the biological effects of $\mathrm{P}^{+}$: ISP are mediated through a common pathway shared with IFN $\alpha$.

Since an immunosuppressive CKS-17-like sequence is also present in IFN $\alpha$, we tried to establish a homologous (chemotactic inhibitory) action between p15E and IFN $\alpha$ $\left(M_{\mathrm{r}}=19,000-26,000[23]\right)$. To verify this possible homologous action, we investigated the effect of rhuIFN $\alpha$ on the chemotactic responsiveness of healthy donor monocytes (measured with the monocyte polarization assay, which represents an early event of the chemotactic responsiveness $[3,24])$. We also established the reactivity of the anti-p15E/ CKS-17 antibodies against rhuIFN $\alpha$ using a dot-blot technique, and vice versa (anti-IFN $\alpha$ antibodies to retroviral p15E). Furthermore, we were interested in whether the p15E-related HNsce low- $M_{\mathrm{r}}$ factors showed IFN $\alpha$ relatedness. We therefore analysed the immunoreactivity of antiIFN $\alpha$ antibodies on tumour specimens and sera of HNscc patients, and compared these data with the immunoreactivity of the anti-p15E/CKS-17 antibodies.

\section{Materials and methods}

Patients. We studied 18 male and 7 female patients, aged $37-72$ years, with HNscc of the oral cavity, larynx and oro- and hypopharynx; stages T1N2-T4N2. All patients were treated by surgery and/or radiotherapy at the department of ear, nose and throat/head and neck surgery of the Dijkzigt University Hospital, Rotterdam, the Netherlands.

After surgery, neoplastic tissues were snap-frozen in liquid nitrogen and stored at $-70^{\circ} \mathrm{C}$. Serum samples were obtained by venapuncture and stored at $-20^{\circ} \mathrm{C}$ until use.

Monoclonal and polyclonal antibodies. Anti-(MuLV)p15E mAb used were 19F8 [25, 26] (IgG2b) and 4F5 [26, 27] (IgG2a). Anti-CKS-17 $\mathrm{mAb}$, directed against CKS-17-cysteine coupled to keyhole limpet haemocyanin (KLH), have been developed at our department (Dr. M. S. Lang, manuscript in preparation). Two anti-CKS-17 mAb were used, ER-IS5 (IgG2b) and ER-IS1 (IgM; called CK1 in [26]).

Anti-rhuIFNo2b mAb (IgG1) and polyclonal antibodies (pAb) (IgGs) were a generons gift from Dr. P. van der Meyde, TNO Health Research, Rijswijk, the Netherlands.

Control antibodies used were: IgG2a and IgG1 (isotype controls: Becton Dickinson), IgG2b (ICN 64-337 (myeloma source), ICN Biomedical Inc., Costa Mesa, Calif., USA), IgM (blood group antigen A, Dakopatts, Copenhagen, Denmark) and IgGs (rabbit anti-ox red blood cells, Seralab Ltd., Crawley Down, GB).
Table 1. Antibodies and their protein concentrations used in different methods

\begin{tabular}{llcc}
\hline Antibodies & \multicolumn{3}{l}{ Final protein concentrations $(\mu \mathrm{g} / \mathrm{ml})$} \\
\cline { 2 - 4 } & $\mathrm{A}$ & $\mathrm{B}$ & $\mathrm{C}$ \\
\hline 4F5 & 25 & 25 & 25 \\
19F8 & 25 & 25 & 25 \\
4F5/19F8 & $\mathrm{ND}$ & $25 / 25$ & $\mathrm{ND}$ \\
ER-IS5 & 25 & 25 & 25 \\
ER-IS1 & 25 & $\mathrm{ND}$ & 25 \\
Anti-IFN $\alpha(\mathrm{mAb})$ & 30 & 30 & 15 \\
Anti-IFN $\alpha$ (pAb) & 10 & 10 & 5 \\
Control IgG2a & 25 & 25 & 25 \\
Control IgG2b & 25 & 25 & 25 \\
Control IgG1 & 30 & 30 & 15 \\
Control IgM & 25 & ND & 25 \\
Control IgGs & 10 & 10 & 5 \\
RaM-PO & 10 & ND & 10 \\
SaR-PO & 10 & ND & 10
\end{tabular}

A, Immunohistochemistry; $\mathrm{B}$, adsorption experiments; $\mathrm{C}$, dot-blot technique; ND, not determined; RaM-PO and SaR-PO, peroxidaselabelled rabbit anti-(mouse $\mathrm{Ig}$ ) and swine anti-(rabbit $\mathrm{Ig}$ )

Secondary antibodies used were swine anti-(rabbit $\mathrm{Ig}$ ) and rabbit anti(mouse $\mathrm{Ig}$ ) conjugated to horseradish peroxidase (SaR-PO and RaMPO) (Dakopatts, Copenhagen, Denmark).

Immunohistochemistry. Sections of $4 \mu \mathrm{m}$ thickness were cut using a cryostat, mounted on glass slides, air-dried and acetone-fixed for $10 \mathrm{~min}$. These sections were pre-incubated with tenfold-diluted normal sera (Dakopatts, Copenhagen, Denmark) depending on the primary antibody step used; normal rabbit serum (using mAb) and normal swine serum (using pAb). The sections were subsequently incubated for $60 \mathrm{~min}$ with the different specific antibodies mentioned above (and controls), washed three times with phosphate-buffered saline (PBS, $\mathrm{pH}$ 7.4), and incubated for $30 \mathrm{~min}$ with peroxidase-conjugated immunoglobulins. Subsequently the sections were stained using chromagen 1,2-diaminobenzidine (Sigma Chemical Corp., St. Louis, USA), and weakly counterstained with haematoxylin. All the steps described were performed at $21^{\circ} \mathrm{C}$, and antibody dilutions were made in PBS/1\% bovine serum albumin (Sigma Chemical Co., St. Louis, USA).

Antibody protein concentrations were used as shown in Table 1.

Isolation of peripheral blood monocytes. Monocytes from healthy donors were isolated via counterflow elutriation centrifugation $[7,12]$. These almost pure monocyte fractions were used to test the effects of low- $M_{\mathrm{r}}$ factors in sera of HNscc patients and rhuIFN $\alpha 2 \mathrm{~b}$ on the po larization assay (see below). In brief, mononuclear cells were separated from $450 \mathrm{ml}$ whole blood of healthy individuals via Percoll centrifugation ( $20 \mathrm{~min}, 1000 \mathrm{~g}$ ). Thereafter, the mononuclear cells were injected into an elutriation centrifugation system (Beckman $\mathbf{J} 21$ centrifuge with a JE-6 elutriation rotor). The elutriation medium was PBS with $13 \mathrm{mM}$ trisodium citrate and $0.5 \%$ human albumin. To separate the different cell populations, the flow rate was kept constant at $20 \mathrm{ml} / \mathrm{min}$, while the rotor speed decreased from 4000 to $0 \mathrm{rpm}$. The fraction collected at $2500 \mathrm{rpm}$ contained $93 \%-97 \%$ non-specific-esterase-positive cells [28]. This fraction was used in further experiments after storage in liquid nitrogen as described previously [12].

The monocyte polarization assay. The Cianciolo and Snyderman [24] assay for monocyte polarization was performed with slight modifications [3]. The outcomes of the assay correlate well with the outcomes of the conventional Boyden chamber assay to measure chemotaxis to formylmethionylleucylphenylalanine (fMetLeuPhe) and casein [3, 24]. Aliquots $(0.2 \mathrm{ml})$ of elutriator-purified cell suspension, containing $0.2 \times 10^{6}$ monocytes thawed and washed in RMPI- 1640 medium sup- 
plemented with $10 \%$ fetal calf serum (Gibco, Breda, the Netherlands), $2 \mathrm{mM}$ glutamine and antibiotics, were added to $12 \times 75-\mathrm{mm}$ polypropylene tubes (Falcon Labware Division of Becton Dickinson Corp., Oxford, Calif., USA) containing $0.05 \mathrm{ml}$ medium or fMetLeuPhe (final concentration of $10 \mathrm{nM}$ ), or with fMetLeuPhe in combination with HNsce low- $M_{\mathrm{r}}$ factors, before and after adsorption with the different antibodies (see below), or rhuIFN $\alpha 2 b$. The tubes were incubated at $37^{\circ} \mathrm{C}$ in a waterbath for $15 \mathrm{~min}$. The incubation was then stopped by addition of $0.25 \mathrm{ml}$ ice-cold $10 \%$ formaldehyde in $0.05 \mathrm{M}$ PBS $(\mathrm{pH} 7.4)$. The cell suspensions were kept at $4^{\circ} \mathrm{C}$ until counting in a haemocytometer using an ordinary light microscope (magnification $250 \times$ ). The test was read "blindly" by two persons; 200 cells were counted from each tube. A cell was "polarized" if any of the following features occurred: (a) elongated or triangular shape; (b) broadened lamellipodia; (c) membrane ruffling.

The percentage of polarized monocytes was calculated as follows:

$$
\frac{\text { total cells polarized }(\%)}{\text { cells positive for non-specific esterase }(\%)} \times 100
$$

Lymphocytes do not exhibit any polarization activity towards fMetLeuPhe [3]. Depending on the donor, $25 \%-40 \%$ of the monocytes polarized in response to MetLeuPhe (spontaneous polarization $4 \%-9 \%)$

The effect of low-molecular-mass factors in sera from patients with head and neck squamous cell carcinoma and recombinant human IFN $22 b$ on the monocyte polarization assay. Sera were collected as mentioned above and diluted $1: 1$ in PBS. These dilutions were subjected to ultrafiltration through Amicon CF25 Centriflo cones (Amicon Corp., Danvers, USA) for $15 \mathrm{~min}$ at $700 \mathrm{~g}$ ( $M_{\mathrm{\Gamma}}$ "cut-off point" 25,000 ). The filtrates, low $-M_{\mathrm{r}}$ factors, were dissolved in PBS and stored at $20^{\circ} \mathrm{C}$.

The capability of low- $M_{\mathrm{r}}$ factors or rhuIFN $\alpha 2 \mathrm{~b}$ (Intron A; Schering Corp., Kenilworth, N.J., USA) to influence the fMetLeuPhe-induced polarization of healthy donor monocytes was determined by incubating the monocytes $\left(1 \times 10^{6} / \mathrm{ml}\right)$ for $15 \mathrm{~min}$ at $37^{\circ} \mathrm{C}$, either with fMetLeuPhe alone, or with the tripeptide in combination with low- $M_{\mathrm{r}}$ factors (final dilution $1: 60$ ) or different concentrations of rhuIFN $\alpha 2 b$ (final concentrations $5 \mathrm{pM}-500 \mathrm{nM}$ ). The percentage inhibition was calculated as follows:

$$
\text { inhibition }(\%)=\left(1-\frac{P_{2}-P_{0}}{P_{1}-P_{0}}\right) \times 100
$$

where $P_{0}=$ spontaneous polarization $(\%), P_{1}=$ polarization after incubation with $\mathrm{fMetLeuPhe}(\%)$ and $P_{2}=$ polarization after incubation with fMetLeuPhe and low- $M_{\mathrm{r}}$ factors or rhuIFN $\alpha$.

Low- $M_{\mathrm{r}}$ factors and rhuIFN $\alpha 2 \mathrm{~b}$ were tested in triplicate, the addition of either of these to donor monocytes unstimulated by fMetLeuPhe did not affect the spontaneous polarization.
Adsorption experiments. To validate the p15E-like character of low- $M_{\mathrm{r}}$ factors, adsorption experiments were performed by neutralizing the factors before testing their effects on the monocyte polarization assay, with anti-p15E antibodies, at $4^{\circ} \mathrm{C}$ for $16 \mathrm{~h}$ and then carrying out Amicon ultrafiltration (see above) to remove the antibody-antigen complexes formed. The same procedures were performed for investigating the expression of the CKS-17 domain with an anti-CKS-17 antibody (ER-IS5) and expression of IFN $\alpha 2 \mathrm{~b}$ determinants with antiIFN $\alpha 2 b$ antibodies. As control antibodies we used irrelevant $\mathrm{mAb}$ and a pAb. Antibody protein concentrations were used as shown in Table 1.

Dot-blot technique. Rauscher MuLV $(\approx 1.0 \mathrm{mg}$ protein/ml), purified as described elsewhere [29] from the JLS-V5 cell line, and rhuIFN $\alpha 2 b$ $(\approx 0.1 \mathrm{mg}$ rhuIFN $\alpha 2 \mathrm{~b} / \mathrm{ml})$ were applied as dots directly onto nitrocellulose strips (Bio-Rad Lab., Richmond, Calif., USA) in 5- $\mu \mathrm{I}$ volumes, and dried at $70^{\circ} \mathrm{C}$ for $1 \mathrm{~h}$. The remaining protein-binding sites were blocked with PBS/0.05\% gelatin (Gibco Europe Ltd., Paisley, Scotland) for at least $1 \mathrm{~h}$. The nitrocellulose strips were then incubated overnight with anti-p15E, anti-CKS-17 and anti-IFN $\alpha 2 b$ antibodies. Bound antibodies were detected with specific conjugates, SaR-PO and RaM-PO, during a 2-h incubation step. All incubations were performed at $21^{\circ} \mathrm{C}$ with slow agitation, and between these steps the strips were washed three times with PBS/0.05\% Tween 20 (Merck, München, Germany). The strips were developed by $0.01 \% \mathrm{H}_{2} \mathrm{O}_{2}$ and $1.7 \mathrm{mM}$ 4-chloro-1-naphthol (J. T. Barker B. V., Deventer, The Netherlands) in $50 \mathrm{mM}$ TRIS/HCl buffer ( $\mathrm{pH} \mathrm{7.2),} \mathrm{7 \%} \mathrm{poly-}$ ethyleneglycol 6000 (Sigma Chemical Co., St. Louis, USA), for 5$10 \mathrm{~min}$. Antibody protein concentrations were used as shown in Table 1.

\section{Results}

\section{Effect of recombinant human IFN $\alpha 2 b$ on the monocyte polarization}

Since IFN $\alpha$ has sequential similarities to retroviral p15E (see Introduction), we were interested in whether it was capable of inhibiting the polarization of healthy monocytes. As shown in Fig. 1, rhuIFN $\alpha 2 b$ strongly inhibited the polarization of healthy monocytes in a dose-dependent manner, with a concentration of half-maximum inhibition (IC $\mathrm{I}_{50}$ ) of about $100 \mathrm{nM}$ (maximum inhibition $100 \% ; P_{2}=P_{0}$, see Materials and methods). This inhibitory activity of rhuIFN $\alpha 2 b$ could not be ascribed to peptide-mediated toxicity: even with the highest concentration tested

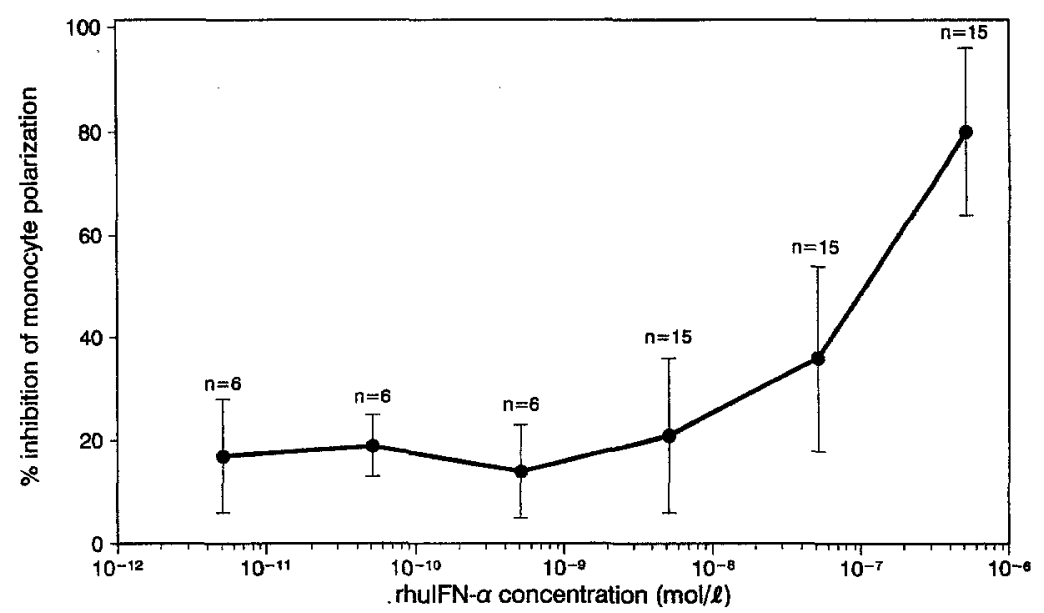

Fig. 1. The percentage inhibition of various concentrations of recombinant human interferon $\alpha 2 b$ (rhuIFN $\alpha 2 \mathrm{~b}$ ) on the fMetLeuPhe-induced monocyte polarization 
A

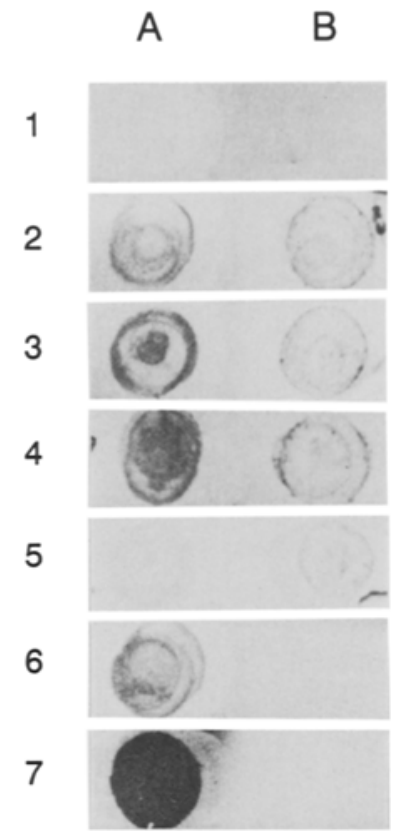

Fig. 2. Immunoreactivity (dot-blot technique) of rhuIFN $\alpha 2 b(A)$ and MuLV-p15E $(B)$ using the following antibodies: a representative Ig control (1), anti-p15E antibodies 4F5 (2), and 19F8 (3), anti-CKS-17 antibodies ER-IS1 (4) and ER-IS5 (5), and anti-IFN $\alpha$ mAb (6) and $\mathrm{pAb}(7)$

$(500 \mathrm{nM})$ and incubation periods of up to $1 \mathrm{~h}$, none of the monocytes showed altered morphology and an increased trypan blue uptake (data not shown).

\section{Dot-blot technique}

To study a possible structural homology between retroviral p15E and human IFN $\alpha$, we also investigated whether the specific antibodies reacted with immobilized rhuIFN $\alpha 2 b$ and/or detergent-disrupted MuLV as a source of p15E, in comparison wih isotype and matched control antibodies. Figure 2 shows that anti-IFN $\alpha$ antibodies reacted with rhuIFN $\alpha 2 b$, but did not show any reactivity with (dot) blotted disrupted MuLV, indicating that these antibodies showed specificity for rhuIFN $\alpha$. The anti-p15E antibodies (19F8 and 4F5) reacted with both rhuIFN $\alpha 2 \mathrm{~b}$ and disrupted $\mathrm{MuLV}$, indicating that these antibodies were not only specific for retroviral p15E but also crossreacted at least to a certain extent with IFN $\alpha$. The anti-CKS-17 antibodies (ERIS5 and ER-IS1) showed differential patterns of reactivity. Whereas ER-IS1 clearly reacted with both rhuIFN $\alpha 2 b$ and MuLV, ER-IS5 only very weakly reacted to disrupted MuLV.

Interestingly, the anti-p15E and anti-IFNo-specific antibodies were also able to adsorb the rhuIFN $\alpha(500 \mathrm{nM})$ inhibitory effect on the monocyte polarization (data not shown), confirming the reactivity of all these antibodies with rhuIFN $\alpha$ shown in the dot-blot experiments.

\section{Reactivity of anti-p15E, anti-CKS-17 and anti-IFN $\alpha$ antibodies with immunosuppressive low-molecular-mass factors from the sera of patients with head and neck squamous cell carcinoma}

Low- $M_{\mathrm{r}}$ factors prepared from the sera of patients with HNscc inhibit the polarization of normal monocytes [6-8]. Table 2 shows the results of adsorption experiments on the low- $M_{\mathrm{r}}$ factors prepared for serum preparations $(n=8-11)$ with the antibodies used in this study (see Table 1). The monocyte chemotaxis-inhibitory effect of all low- $M_{\mathrm{r}}$ factors tested could be adsorbed - as has been reported before - by the anti-p15E antibodies 19F8 ( 3 out of 3 HNscc sera tested) and 4F5 ( 3 out of 3) just as well as by a mixture of these two $\mathrm{mAb}$ (8 out of 8 ).

Table 2. The percentages inhibition by low- $M_{\mathrm{r}}$ factors prepared from sera of patients with head and neck squamous cell carcinoma on the fMetLeuPhe-induced monocyte polarization, before and after adsorption with antibodies directed against retroviral MuLV-p15E, its putative immunosuppressive (synthetic) CKS-17-region and rhuIFN $\alpha$; the difference in inhibition of the polarization after adsorption between specific antibodies and their matching isotype controls was evaluated using the Wilcoxon's rank-sum test

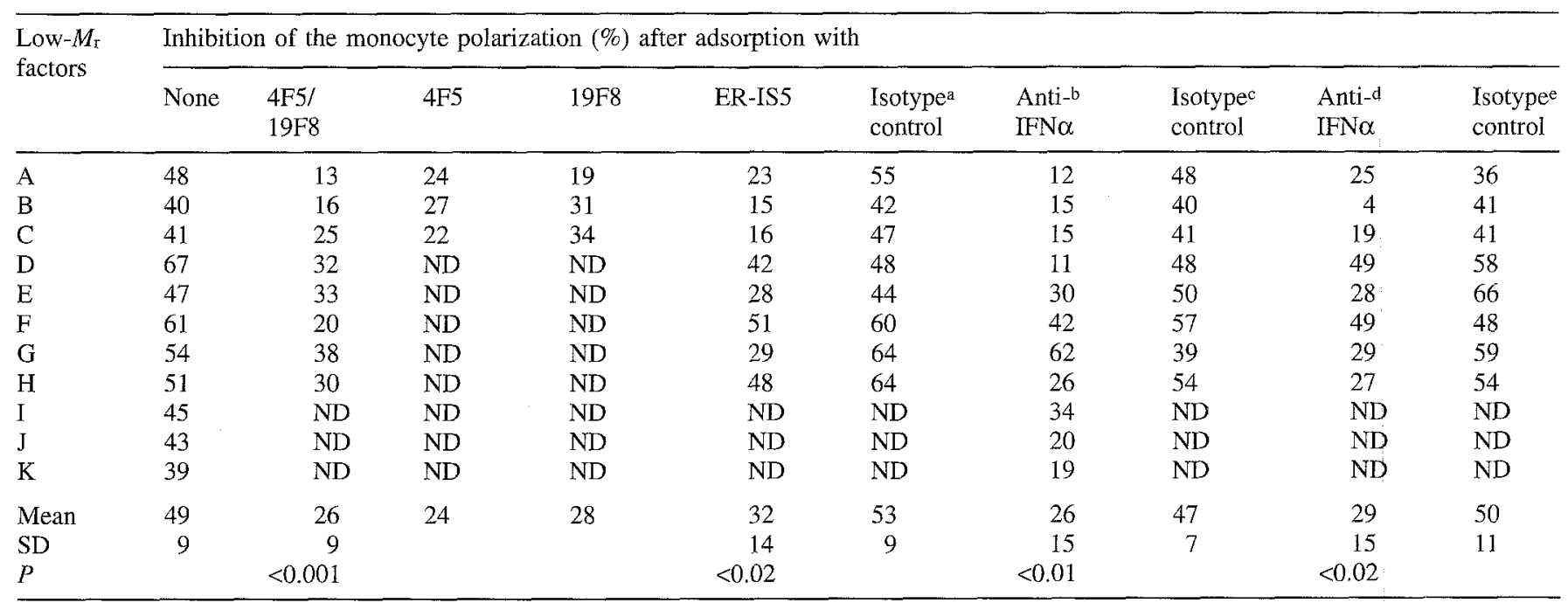

$\mathrm{ND}$, not determined; a IgG2a/b; b $\mathrm{mAb}$; ${ }^{\mathrm{IgG} 1}$; ${ }^{\mathrm{p}} \mathrm{pAb}$; e IgGs 

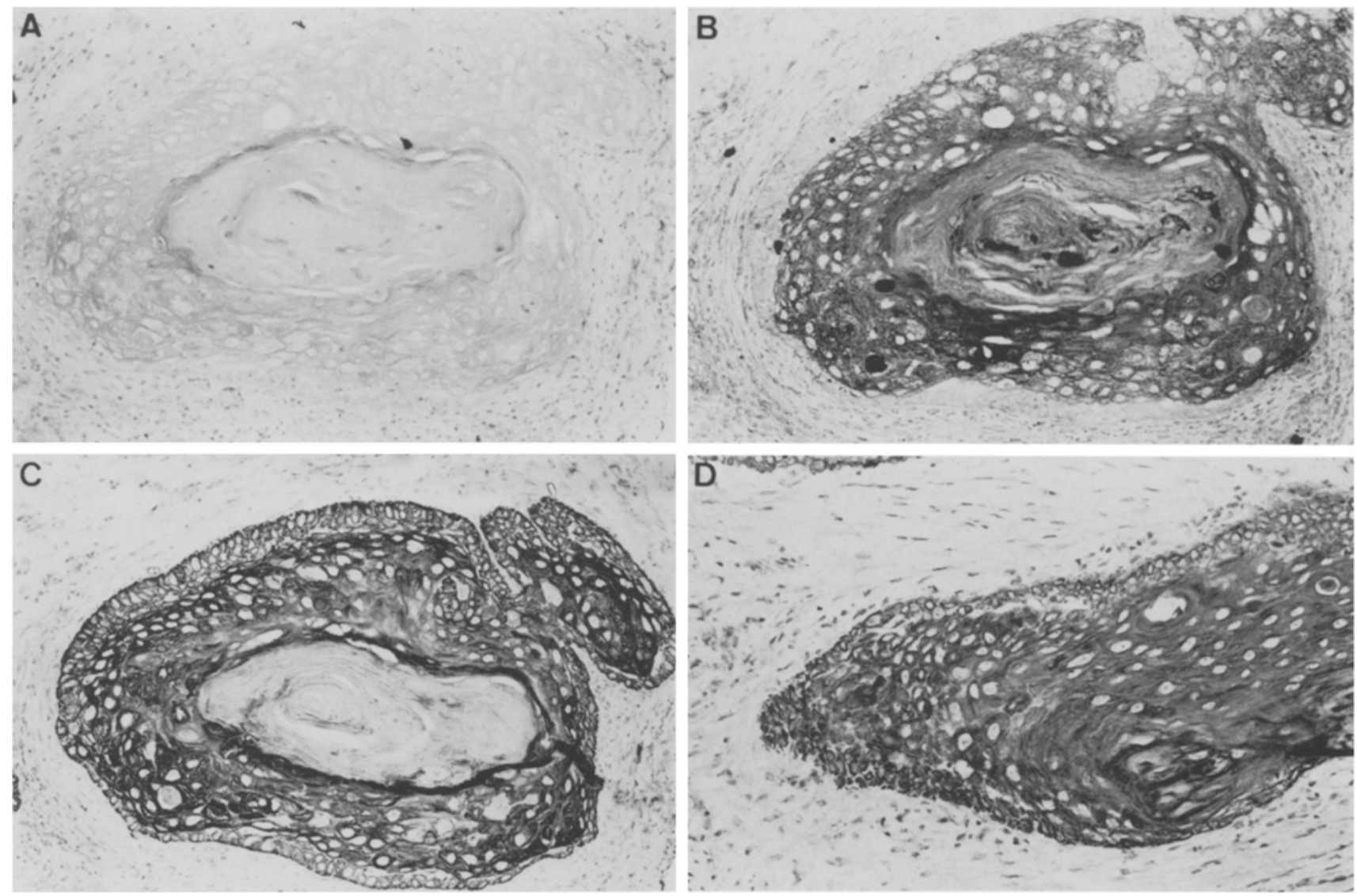

Fig. 3A-D. Immunohistochemical staining of head and neck squamous cell carcinoma specimens using the following antibodies: a representative Ig control (A), anti-p15E antibody 4F5 (B), anti-IFN $\alpha$ pAb (C) and anti-CKS-17 antibody ER-IS1 (D) (magnification 150 $\times$ )

Interestingly, anti-IFN $\alpha 2 b \mathrm{mAb}$ and $\mathrm{pAb}$ were also capable of adsorbing the inhibitory effect of the low- $M_{\mathrm{r}}$ factors. Since the anti-IFN $\alpha$ antibodies are specific to IFN $\alpha$ (dot-blot technique) and do not react with MuLV-p15E, the data of Table 2 must be taken as evidence that the majority of the low-Mr factors do contain IFN $\alpha$-like molecules as immunosuppressive factors.

However, we could not find a correlation between the adsorption capabilities of the anti-IFN $\alpha$ antibodies and the anti-p15E antibodies, and it is thus possible that the low- $M_{\mathrm{r}}$ factors contain both $\mathrm{p} 15 \mathrm{E}$ - and IFN $\alpha$-related factors. It is also possible that different affinities of the antibodies, together with heterogeneity of the low- $M_{\mathrm{r}}$ factors, explain the non-correlation.

The relatively weak (as shown in the dot-blot experiment) anti-CKS-17 mAb ER-IS5 adsorbed the inhibitory activity of these inhibitory low- $M_{\mathrm{r}}$ factors to a certain extent ( 6 out of 8 ), indicating that these low- $M_{\mathrm{r}}$ factors express the CKS-17-like domain, as has been demonstrated previously [26].

Immunohistochemistry of head and neck squamous cell carcinoma specimens with anti-p15E, anti-CKS-17 and anti-IFN $\alpha$ antibodies

In accordance with our previous reports $[5,26]$ all $(n=18)$ HNscc tissue specimens studied showed a positive reactivity with both anti-retroviral p15E antibodies used, namely $19 \mathrm{~F} 8$ and $4 \mathrm{~F} 5$. These antibodies recognize different epitopes on retroviral p15E [27]; 19F8 is directed to an epitope in the CKS-17 domain [26]. Antibody 4F5 gave the best results in the immunohistochemistry (Fig. 3b), with practically no background staining. The positivity with the antibodies was mainly detected in corneal layers of welldifferentiated tumours, and in the granular epithelial cells and prickle cells, staining the whole cytoplasm. Basal cells close to the basal membrane were often negative.

Anti-IFN $\alpha \mathrm{mAb}$ and $\mathrm{pAb}$ also gave positive staining results with almost all (17/18) HNscc tumour specimens. However, the location of the reactivity was different from that of the anti-p15E antibodies, particularly in the case of the anti-IFN $\alpha$ pAb (Fig. 3c). This latter antibody clearly reacted with malignant cells in the basal epithelial cell layers close to the basal membrane, as well as with the prickle cell layers. Though this antibody was often reactive to some extent to granular cells and the corneal layers, this reactivity was not as strong as the reactivity with the antip15E antibodies.

The anti-CKS-17 antibodies, ER-IS5 and ER-IS1, gave staining results combining the results of the anti-p15E and anti-IFN $\alpha$ antibodies: in fact, all layers of the tumours were clearly reactive with these antibodies. It must be noted that ER-IS1 gave for stronger immunostaining results (Fig. 3d) than did ER-IS5, which appeared to be an antibody with low affinity (see dot-blot and adsorption experiments). 


\section{Discussion}

In the present study we have shown that rhuIFN $\alpha b$ shares functional (monocyte polarization experiments) and structural (dot-blot technique) homology to retroviral p15E. Furthermore, our data show that low- $M_{\mathrm{r}}$ factors, prepared from the sera of HNscc patients, do not only contain factors related to retroviral p15E (as was shown extensively in earlier studies), but also factors that show antigenic similarity to IFNo. These factors appear to be separate, since there were discrepancies found in (a) the low- $M_{\mathrm{r}}$ factor adsorption data and (b) the immunohistochemistry staining results with anti-p15E and anti-IFN $\alpha$ antibodies.

IFN $\alpha\left(M_{\mathrm{r}}=19,000-26,000\right.$ [23]), well known for its antiviral actions [30], has been reported to have a wide range of immunosuppressive activities. In vivo, IFN $\alpha$ has been shown to decrease DTH responses in mice sensitized with sheep red blood cells [31]. In addition, the generation of antibody-producing cells was inhibited by IFN $\alpha$ when it was administered prior to sensitization with sheep red blood cells [32]. In vitro, IFN $\alpha$ is antiproliferatively active [30] and suppresses T-helper lymphocytes to stimulate antibody production by B lymphocytes [33]. Furthermore, functional suppression of monocytes/macrophages has been described: inhibition of IFN $\gamma$-induced-HLA-DR expression [34], -tumoricidal activity [35] and -respiratory burst [36] on macrophages, and blocking of IL-1-induced prostaglandin release from monocytes [37] (IL-1 inhibitor). Moreover, IFN $\alpha$ suppresses the in vitro maturation from human monocytes to macrophages (down-regulation of phagocytosis, complement receptors and lysosomal enzymes [38]).

In this report we complement these functional studies on IFN $\alpha$ by showing that rhuIFN $\alpha 2 b$ also inhibits fMetLeuPhe-induced monocyte polarization. Furthermore, using a modified Boyden chamber assay it was found that the classical chemotaxis is suppressed by rhuIFN $\alpha 2 b$ (unpublished observation). Interestingly, the inhibitory activities on monocyte polarization of rhuIFN $\alpha 2 b$ were adsorbed by the anti-retroviral $\mathrm{p} 15 \mathrm{E}$ antibodies. One of the latter antibodies, 19F8, recognizes an epitope within the immunosuppressive CKS-17 domain [26]. It is of particular interest that the sequence recognized by this $\mathrm{mAb}$, LQNRRGLD (one-letter amino-acid code), is the sequence that is most similar to a homologous sequence within IFN $\alpha$ $[21,22]$. This sequence has been postulated to be the minimally required sequence for immunosuppressive activity [16]. Previous studies $[21,22]$ have shown that the putative immunosuppressive site of retroviral p15E, CKS17, also has IFN $\alpha$-like antiviral and antiproliferative activities. Moreover, our adsorption results suggest that a sequence similar to LQNRRGLD is clearly expressed in the immunosuppressive serum factors from HNscc patients.

With regard to our finding of the IFN $\alpha$-relatedness of at least some of the (HNscc sera) low- $M_{\mathrm{r}}$ factors, Sato et al. [39] have earlier found IFN activity in the sera of HNscc patients. This activity was abrogated with acid treatment. In other patient groups characterized by clear immune disorders, such as patients with systemic lupus erythematosus [40] or AIDS [41], atypical acid-labile IFN $\alpha$ has been demonstrated. It must be noted, however, that this acid lability was due to an acid-labile molecule, associated with, but distinct from "normal" (acid-stable) IFNo $[42,43]$. In humans, it has been shown that there are at least 15 highly related IFN $\alpha$ subtypes [23], each with characteristic chemical and biological activities. For instance, while IFN $\alpha$ is generally known to be an activator of NK cell activity [30], the subtype IFN $\alpha J$ lacks this ability and may even block the NK-boosting activity of other IFNo subtypes [44] (e.g. IFN $\alpha$ A). Hence, IFN $\alpha$ subtypes may exist that antagonize the immunostimulating activities of other subtypes and may even be primarily immunosuppressive.

It is tempting to suggest that the immunosuppressive factors found in HNscc are in fact related to these subtypes of IFNo, and even that p15E-related factors may be included in the IFN $\alpha$ family.

In conclusion, antigenic similarities observed in this study between p15E, its synthetic CKS-17 domain and human IFN $\alpha$, and their known immunosuppressive action on different immunocompetent "target" cells, suggest a relationship between inhibitory HNscc p15E-related factors and human IFN $\alpha$. It is likely that HNscc produce a set of heterogeneous factors that are IFN $\alpha$ - and/or p1.5E-related and exhibit inhibitory effects on monocyte chemotaxis. Isolation, purification and sequencing of $\mathrm{HNscc}$ immunosuppressive factors is of the utmost importance to determine whether these ill-defined factors are indeed related to the IFN $\alpha$ family, form a separate variety of products of (endogenous) retroviruses or represent crossreacting activities.

Acknowledgements. We would like to thank Dr. M. S. Lang for preparation of the anti-CKS-17 antibodies and MuLV samples, Mr. T. M. van Os for excellent photographs and figures, Ms. A. C. de Vries for secretarial support, Dr. A. J. M. Balm for critical comments on the manuscript, and Dr, P. P. M. Knegt and Dr. J. Kerrebijn for providing tissue specimens, blood samples and clinical data of the HNscc patients.

\section{References}

1. Cortesina G, Sacchi M, Galeazzi E, De Stefani A (1993) Immunology of head and neck cancer: perspectives. Head Neck 14: 74

2. Balm AJM, Drexhage HA, von Blomberg-van der Flier BME, Weltevreden EF, Veldhuizen RW, Mullink H, Snow GB (1984) Mononuclear phagocyte function in head and neck cancer: the chemotactic responsiveness of blood monocytes in correlation to the histological grade of the tumour and the infiltration of these cells into the tumour area. Cancer 54: 1010

3. Tan IB, Drexhage HA, Scheper RJ, von Blomberg-van der Flier BME, de Haan-Meulman M, Snow GB, Balm AJM (1986) Defective monocyte chemotaxis in patients with head and neck cancer. Restoration after treatment. Arch Otolaryngol Head Neck Surg 112: 541

4. Tan IB, Drexhage HA, Scheper RJ, von Blomberg-van der Flier BME, de Haan-Meulman M, Snow GB, Balm AJM (1986) Immunosuppressive retroviral p15E-related factors in head and neck carcinomas. Arch Otolaryngol Head Neck Surg 112: 942

5. Tan IB, Drexhage HA, Mullink H, Hensen-Logmans SC, de HaanMeulman M, Snow GB, Balm AJM (1987) Immunohistochemical detection of retroviral p15E-related material in carcinomas of the head and neck. Otolaryngol Head Neck Surg 96: 251

6. Tan IB, Balm AJM, Snow GB, Drexhage HA (1990) Immunosuppressive retroviral-related factors in sera of patients with head and neck cancer. Eur Arch Otorhinolaryngol 247: 387 
7. Tas M, Simons PJ, Balm AJM, Drexhage HA (1993) Depressed monocyte polarization and clustering of dendritic cells in patients with head and neck cancer: in vitro restoration of this immunosuppression by thymic hormones. Cancer Immunol Immunother 36: 108

8. Tas M, Laarman D, de Haan-Meulman M, Balm AJM, Snow GB, Drexhage HA (1993) Retroviral p15E-related serum factors related to recurrence of head and neck cancer. Clin Otolaryngol 18: 324

9. Snyderman R, Cianciolo GJ (1984) Immunosuppressive activity of the retroviral envelope protein $\mathrm{p} 15 \mathrm{E}$ and its possible relationship to neoplasia. Immunol Today 5: 240

10. Oostendorp RAJ, Meijer CLJM, Scheper RJ (1993) Immunosuppression by retroviral-envelope-related proteins, and their role in non-retroviral human disease. Crit Rev Oncol Hematol 14: 189

11. Cianciolo GJ, Kipnis RJ, Snyderman R (1984) Similarity between p15E of murine and feline leukaemia viruses and p21 of HTLV. Nature 311: 515

12. Oostendorp RAJ, Schaaper WMM, Post J, Meloen RH, Scheper RJ (1992) Synthetic hexapeptides derived from the transmembrane envelope proteins of retroviruses suppress $N$-formylpeptide-induced monocyte polarization. J Leukoc Biol 51: 282

13. Kleinerman ES, Lachman LB, Knowles RD, Snyderman R, Cianciolo GJ (1987) A synthetic peptide homologous to the envelope proteins of retroviruses inhibits monocyte-mediated killing by inactivating interleukin 1. J Immunol 139: 2329

14. Harrell RA, Cianciolo GJ, Copeland TD, Oroszlan S, Snyderman R (1986) Suppression of the respiratory burst of human monocytes by a synthetic peptide homologous to envelope proteins of human and animal retroviruses. J Immunol 136: 3517

15. Cianciolo GJ, Copeland TD, Oroszlan S, Snyderman R (1985) Inhibition of lymphocyte proliferation by a synthetic peptide homologous to retroviral envelope proteins. Science 230: 453

16. Ruegg CL, Monell CR, Strand M (1989) Identification, using synthetic peptides, of the minimum amino acid sequence from the transmembrane protein $\mathrm{p} 15 \mathrm{E}$ required for inhibition of lymphoproliferation its similarity to gp 21 of human T-lymphotropic virus types I and II. J Virol 63: 3250

17. Mitani M, Cianciolo GJ, Snyderman R, Yasuda M, Good RA, Day NK (1987) Suppressive effect on polyclonal B-cell activation of a synthetic peptide homologous to a transmembrane component of oncogenic retroviruses. Proc Natl Acad Sci USA 84: 237

18. Ogasawara M, Cianciolo GJ, Snyderman R, Mitani M, Good RA, Day NK (1988) Human IFN- $\gamma$ production is inhibited by a synthetic peptide homologous to retroviral envelope protein. J Immunol 141: 614

19. Harris DT, Cianciolo GJ, Snyderman R, Argov S, Koren HS (1987) Inhibition of human natural killer cell activity by a synthetic peptide homologous to a conserved region in the retroviral protein, p15E. J Immunol 138: 889

20. Nelson M, Nelson DS, Cianciolo GJ, Snyderman R (1989) Effects of CKS-17, a synthetic retroviral envelope peptide, on cellmediated immunity in vivo: immunosuppression, immunogenicity and relation to immunosuppressive tumor products. Cancer Immunol Immunother 30: 113

21. Ruegg CL, Strand M (1990) Identification of a decapeptide region of human interferon-alpha with antiproliferative activity and homology to an immunosuppressive sequence of the retroviral transmembrane protein p15E. J Interferon Res 10:621

22. Wegemer DE, Kabat KG, Kloetzer WS (1990) Biological activities of a synthetic peptide composed of two unlinked domains from a retroviral transmembrane protein sequence. J Virol 64: 1429

23. Pestka S (1992) Interferon- $\alpha$. In: Aggarwal BB, Gutterman JU (eds) Human cytokines: handbook for basic and clinical research. Blackwell, Cambridge, Mass, USA, p1

24. Cianciolo GJ, Snyderman R (1981) Monocyte responsiveness to chemotactic stimuli is a property of a subpopulation of cells that can respond to multiple chemoattractants. J Clin Invest 67: 60
25. Lostrom ME, Stone MR, Tam M, Burnette WN, Pinter A, Nowinski RC (1979) Monoclonal antibodies against murine leukemia viruses: identification of six antigenic determinants on the p15(E) and gp70 envelope proteins. Virology 98: 336

26. Oostendorp RAJ, Lang MS, Puijk WC, Simons PJ, Meloen RH, Ewijk W van, Meyer CJLM, Scheper RJ (1992) Immunoreactivity of a monoclonal antibody against CKS-17, the putative immunosuppressive region of retroviral transmembrane proteins. Comparison with known monoclonal antibodies against MuLVp15E. In: Oostendorp RAJ (ed) Immunosuppression by retrovirusderived peptides. VU University Press, Amsterdam, p 137

27. Cianciolo GJ, Lostrom ME, Tam M, Snyderman R (1983) Murine malignant cells synthesize a 19,000-Dalton protein that is physicochemically and antigenically related to the immunosuppressive retroviral protein, p15E. J Exp Med 158: 885

28. Mullink $\mathrm{H}$, von Blomberg-van der Flier BME, Wilders MM, Drexhage HA, Alons CL (1979) A simple cytochemical method for distinguishing EAC rosettes formed by lymphocytes and monocytes. J Immunol Methods 29: 133

29. Duesberg PH, Robinson WS (1966) Nucleic acid and proteins isolated from the Rauscher mouse leukemia virus (MLV). Proc Natl Acad Sci USA 55: 219

30. Ozes ON, Reiter ZVI, Klein S, Blatt LM, Taylor MW (1992) A comparison of interferon-con 1 with natural recombinant interferons- $\alpha$ : antiviral, antiproliferative, and natural killer-inducing activities. J Interferon Res 12: 55

31. De Maeyer E, De Maeyer-Guignard J, Vandeputte M (1975) Inhibition by interferon of delayed-type hypersensitivity in the mouse. Proc Natl Acad Sci USA 72: 1753

32. Strannegård Ö, Larsson I, Lundgren E, Miörner H, Persson H (1978) Modulation of immune responses in newborn and adult mice by interferon. Infect Immun 20: 334

33. Brinkman V, Heusser CH, Baer J, Kilchherr E, Erard F (1992) Interferon- $\alpha$ suppresses the capacity of $T$ cells to help antibody production by human B cells. J Interferon Res 12: 267

34. Inaba $\mathrm{K}$, Kitaura M, Kato T, Watanabe Y, Kawade Y, Muramatsu S (1986) Contrasting effect of $\alpha / \beta$ - and $\gamma$-interferons on expression of macrophage Ia antigens. J Exp Med 163: 1030

35. Saiki I, Dunegan MA, Fann AV, Koff WC (1986) Regulatory effects on macrophages of human recombinant interferons- $\alpha$. J Interferon Res 6: 603

36. Garotta G, Talmadge KW, Pink JRL, Dewald B, Baggiolini M (1986) Functional antagonism between type I and type II interferons on human macrophages. Biochem Biophys Res Commun 140: 948

37. Browning JL, Ribolini A (1987) Interferon blocks interleukin 1induced prostaglandin release from human peripheral monocytes. J Immunol 138: 2857

38. Becker S (1984) Influence of interferon on human monocyte to macrophage development. Cell Immunol 84: 145

39. Sato M, Yoshida H, Yanagawa T, Yura Y, Urata M, Atsumi M, Furumoto N, Hayashi Y, Takegawa Y (1984) Interferon activity and its characterization in sera of patients with head and neck cancer. Cancer 54: 1239

40. Preble OT, Black RJ, Friedman RM, Klippel JH, Vilcek J (1982) Systemic lupus erythematosus: presence in human serum of an unusual acid-labile leukocyte interferon. Science 216: 429

41. DeStefano E, Friedman RM, Friedman-Kien AE, Goedert JJ, Henriksen D, Preble OT, Sonnabend JA, Vilcek J (1982) Acidlabile human leucocyte interferon in homosexual men with Kaposi's sarcoma and lymphadenopathy. J Infect Dis 146: 451

42. Yee AMF, Buyon JP, Yip YK (1989) Interferon $\alpha$ associated with systemic lupus erythematosus is not intrinsically acid labile. J Exp Med 169: 987

43. Capobianchi MR, Mattana P, Mercuri F, Conciatori G, Ameglio F, Ankel H, Dianzani F (1992) Acid lability is not an intrinsic property of interferon- $\alpha$ induced by HIV-infected cells. J Interferon Res 12: 431

44. Langer JA, Ortaldo JR, Pestka S (1986) Binding of human alphainterferons to natural killer cells. J Interferon Res 6:97 